\title{
"Madam Speaker, these are colleagues who are learning to speak, can I allow them to speak?": Gendered performances and ethnographic observations in the Parliament of Uganda
}

\author{
Amon Ashaba Mwiine \\ Department of Sociology and Social Anthropology, \\ Faculty of Arts and Social Sciences, \\ Stellenbosch University, South Africa \\ Email: amonmwiine@gmail.com
}

\begin{abstract}
This paper is based on an ethnographic study I conducted in the Parliament of Uganda in 2016. It draws on observation of live parliamentary debates to investigate ways gender power relations are played out in everyday public interactions between and among female and male legislators and how these performances construct and reproduce parliament as a difficult place for female legislators to engage in be taken seriously. Informed by narrative analysis and feminist theories of gender performativity, the paper argues for and seeks to exemplify a methodological and analytical approach which focuses not just on what women and men say, but also how they say it and the emotions conveyed. Findings indicate how male MPs disrupt and denigrate female colleagues through hilarity, bullying, jeers, and cheers. The paper argues that repeated male MPs' infantilisation and trivialisation of female MPs' actions point to how problematic parliament is for women. Thus, it is hardly surprising that female MPs at times opt for men to introduce and speak to motions concerned with promoting women's rights.
\end{abstract}

Keywords: gender; power; male champions; performativity; ethnography of parliament; parliamentary debates.

Reference to this paper should be made as follows: Mwiine, A.A. (2019) " "Madam Speaker, these are colleagues who are learning to speak, can I allow them to speak?": Gendered performances and ethnographic observations in the Parliament of Uganda', Int. J. Gender Studies in Developing Societies, Vol. 3, No. 1, pp.60-74.

Biographical notes: Amon Ashaba Mwiine is a PhD candidate in Sociology in the Department of Sociology and Social Anthropology, Faculty of Arts and Social Sciences, Stellenbosch University, South Africa. He specialises in sociological understanding of everyday ways of doing gender [and power] in political institutions. His current $\mathrm{PhD}$ project is exploring the emerging phenomenon of 'male champions' - men who speak to issues of gender on behalf of women - in legislative processes. He is an Assistant Lecturer at the School of Women and Gender Studies, Makerere University in Uganda and has taught courses such as gender and sexuality and men, masculinities and development. His research interests are in participatory forms of qualitative research; gender power dynamics and critical masculinity studies. 


\section{Introduction}

Drawing on men as a tactic to mobilise support for pieces of legislation that seek to challenge gender inequalities is increasingly gaining prominence in legislative processes in Uganda and beyond (Tamale, 1999; Powley and Pearson, 2007; Carlson and Randell, 2013; Palmieri, 2013; Wang, 2013; Ahikire and Mwiine, 2015). Tamale (1999) for instance credits using men to 'champion' legislation that challenges gender inequalities as a kind of pragmatism that is a necessary compromise in any negotiations between unequal parties. Similarly, Wang (2013) identifies as critical the role of male allies of the female parliamentary caucus in the passing of pro-women legislation in the 8th parliament (2006-2011).

While the categories 'male champions', and 'allies' are frequently used to label men in parliament who are recruited by women activists to support and speak to issues of gender on women's behalf, little is known about the everyday context in parliament that necessitates the selection of some men to promote gender issues on behalf of women and the implications of this. This paper, thus, draws on ethnographic observation of parliament in 2016, in conjunction with analysis of the Hansard - the official record of parliamentary proceedings - to explore how everyday experiences of female and male legislators might necessitate men as spokespersons of women on issues of gender in parliamentary debates. In particular, the paper does not focus on the formal tabling and discussion of gender-sensitive motions. Rather, it focuses specifically on how the informal and everyday ways gender power relations are played out in the interactions between and among female and male legislators and demonstrates ways in which these gendered performances constitute parliament as a difficult space for women to engage in and be taken seriously. This paper is part of an ongoing $\mathrm{PhD}$ project that is exploring the strategy of promoting gender sensitive legislation through the involvement of male parliamentarians who have been constructed as 'champions' of gender equality (Tamale, 1999).

\section{Brief history on the gendering of parliament in Uganda}

World over, advocacy towards women's political participation is an age-old phenomenon as demonstrated through the global human rights frameworks and national efforts that acknowledge rights of women to participate in public spaces (Ahikire et al., 2015). In Uganda, women's inclusion into legislative politics took protracted women's activists' call to the government to adopt policy reforms that would enable women access and participation in the public sphere. After its ascension to power, the national resistance movement (NRM) government accepted women activists' demands for affirmative action, that is, through reserving a particular quota of women representatives in the legislature and local governments. Each district as a political, administrative unit and a geographical constituency was mandated to elect a women representative to sit in the national legislature. Women were also free to contest with men for the mainstream seats in parliament. Since its inception, affirmative action policy delivered tremendous numbers of women ${ }^{1}$ from $50(18 \%)$ women of the total 280 MPs in 1989 to the current 139 (33\%) women out of the total 289 MPs [Madanda, (2017), p.177]. 
Despite women's increased presence in parliament, Sylvia Tamale (1999) alerts us to the challenges women MPs encountered in deliberating especially on pro-women issues in parliament. In her publication, When Hens Begin to Crow: Gender and Parliamentary Politics in Uganda - which draws on "popular mythology that female chickens do not crow", Tamale recounts men's opposition to women contesting political office and raising and debating gender equity issues in parliament. She decries the ways in which African patriarchal values constrain women's speech in public politics compelling women to adopt 'compromise', 'concessions' and 'trade-offs' as the only plausible ways newly elected women would make their concerns heard in parliament. One such compromise was women's identification of and working with men to speak to gender issues on their behalf. Highlighting this as a strategic manoeuvre by the new entrants to push their issues on the legislative agenda, Tamale noted:

\begin{abstract}
"Acting collectively, women legislators were able to challenge patriarchy, chauvinism and powerlessness to secure a 'women-friendly' constitution. The strategy was to draw as many sympathetic and moderate male constituent assembly delegates to their side as possible in order to augment their numbers" [Tamale, (1999), p.116]. ${ }^{2}$
\end{abstract}

Reference is also made to strategic negotiations in which some women legislators were requested by fellow women to "tone down the language of their demands, as well as selecting a soft-spoken woman or even a man to present the women's case in a moderate manner acceptable to most men" [Tamale, (1999), p.117].

More than two decades on, Uganda has a Constitution that outlawed discrimination on the basis of sex, has institutionalised affirmative action that ushered in high numbers of female legislators than before, as well as registering progress with regard to pro-women legislative reforms (Wang, 2013; Ahikire and Mwiine, 2015). Yet, despite these milestones, there are studies (see Ahikire and Mwiine, 2015; Uganda Women Parliamentary Association, 2016) on how women gender activists continue to draw on men to speak to gender issues on behalf of women in parliamentary and in other cases, labelling these as 'male champions'. This paper, therefore, set out to explore the context of parliament, i.e., examining how everyday experiences of female and male MPs might constitute parliament as a difficult space for female legislators to engage in and be taken seriously necessitating men to speak to gender issues on women's behalf.

\title{
3 Methodology and the theoretical framework
}

To address these concerns, I observed five live parliamentary debate sessions in the 10th parliament (August 2016). Each session was observed using a semi-structured observation guide with a focus on general themes such as etiquette of parliament, women and men's enactment of gender and power through the use of language, holding the floor, speaking strategies. Direct observation was informed by feminist ethnography which pays attention to documenting women's lives, and activities previously seen as marginal and subsidiary to men's (Bryman, 2012; Pillow and Mayo, 2012; Skeggs, 2001). I complemented ethnographic observation of parliament with analysis of the Hansard which enabled me to pay attention not only to 'what' legislators said during live debate sessions but also 'how' they said it and the emotions conveyed. 
My interest in researching parliament this way is influenced by feminist theories of performativity and the sociology of everyday life to analyse everyday interactions of female and male legislators in parliament (Butler, 1990, 1988; West and Zimmerman, 1987; Goffman, 1959) and how these facilitate or constrain female speech. In particular, I focus on parliament as a 'theatre' and explore what goes on in the day to day lives of female and male legislators once they are in presence of each other during debate sessions (Burns, 1992; Goffman, 1959). I ask; how do men and women orient towards each other? What subjective positions do they take on and why? What impact do these performances have on women and men's ways of promoting gender issues in parliament? I underscore the importance of parliament as a stage upon which women and men members act out their gender, social status, age and seniority through what they choose to say or do and implications of these performances for effective legislative engagement.

I also draw on narrative analysis that looks at how social life is organised and presented through stories (Cortazzi, 2001; Andrews et al., 2008; Riessman, 1993, 2001). In particular, I use narrative analysis to examine stories collaboratively told by members of parliament during debate sessions as they are recorded in the Hansard. This focus on narratives departs from the social realist approach which gives prominence to objective truth, to investigate people's investedness in choosing to organise human actions in particular ways (Riessman, 1993) and the implications of these choices in the construction of legislative spaces. Further, narratives can also be analysed as a social process or performance in action, especially where stories are told with the audience in mind [Cortazzi, (2001), p.388]. Conceptualising parliament as a theatre opens up space for me to interrogate how the Hansard as a 'true' record of parliamentary debates captures 'all' that transpires in parliamentary debates including non-verbal expressions and the meanings these convey about the character of parliament as a legislative space.

I also engage with the psychoanalytic concept of otherness (Kitzinger and Wilkinson, 1996) to explore mechanisms through which people are constructed as the other in everyday life. While discussing the notion of other, [Kitzinger and Wilkinson, (1996), p.8] argue that:
"[a] key aspect of various theoretical approaches to othering ... is the observation that the notion of who and what others are (what they are like, the attributes assigned to them, the sort of lives they are supposed to lead) is intimately related to 'our' sense of who and what 'we' are. That is, 'we' use the other to define ourselves: 'we' understand ourselves in relation to what 'we' are not."

What emerges from this conceptualisation is the politics of representation of self and the other in hierarchical ways, dynamic power relations and the projection of any fears, discomfort, desires, and anxieties onto the other. Some of the ways otherness is constructed in everyday life are when some people are constituted as 'speaking subjects' over others (Kitzinger and Wilkinson, 1996). This makes the concept other central to my study especially in relation to the overall objective which is about an investigation on the conditions under which some men come to come to speak about or speak for women on issues of gender in legislative debates rather than women being constituted as subjects in discourse. 


\subsection{Gender power dynamics in parliamentary debates}

In this section that follows, I will draw on specific examples of what I observed in parliamentary debates and compare these with what the Hansard recorded to inform my analysis of gender power relations. I then point out what I consider as significant, issues that do not get picked on for discussion or get recorded in Hansard and the implications this has in understanding the gendering of institutions such as parliament. In particular, I present and discuss certain moments of MPs' interactions in parliamentary debates to illustrate how gender power dynamics play out in their everyday lives and how they exemplify parliament as a difficult place for women to engage meaningfully and be taken seriously. The examples I draw on, namely, 'maiden speech' and the concerns raised about crossing the busy road were common phenomena that female and male legislators related to differently.

\section{Findings}

\subsection{Female MPs and the 'maiden speeches' in parliament}

A maiden speech is the first communication that a member of parliament gives on the floor of the house. Under the rules of procedure of the Parliament of Uganda, maiden speeches are not supposed to be interrupted. For instance, rule 74 (e) indicates that "a maiden speech shall not be interrupted except by the speaker or in circumstances which in the opinion of the speaker warrant interruption." On the contrary, the extract below shows how the maiden speech by a new female MP who doubles as a minister, unfolds amid interruptions. The extract begins with the female MP giving a ministerial statement on the state of blood transfusion services in the country.

The Minister of State for Health (primary healthcare) (Dr. Joyce Moriku): Madam Speaker, I am here to present a comprehensive statement on Uganda Blood Transfusion Services, in regard to the concern that was raised. ... The Uganda Transfusion Services operates within the framework of the national health policy and a health strategic plan. The Uganda Transfusion Services, through its vision and mission - Madam Speaker, this is my maiden statement and for that matter (laughter) - I request that I complete the statement uninterrupted.

The speaker: allow the minister to make her maiden statement first. (Applause)

Ms. Moriku: through the vision and mission, it is mandated to make available adequate quantity of safe blood and blood components for the clinical management of patients that require blood transfusion at all health facilities. That is the mandate of Uganda Blood Transfusion Services ...

Mr. Nathan Nandala Mafabi (FDC [Forum for Democratic Change, an opposition political party], Budadiri County West, Sironko): thank you, Madam Speaker. I am also going to ask maiden questions. (Laughter) the minister said she wanted protection because it was a maiden speech. What is wrong with that? [what's wrong with asking a maiden question then? My emphasis] Madam Speaker, I would like to first thank the Minister of Health for coming up with a statement like that one... 


\begin{abstract}
Ms. Jacquiline Amongin: Madam Speaker, I would like to give information because hon. Nandala mentioned that members should develop the attitude of donating blood. I want to inform this house that not all blood you donate is useful. Therefore, that needs to be clarified - (interruption).
\end{abstract}

Mr. Nandala-Mafabi: Madam Speaker, you can see it has generated maiden information. Given that these are my colleagues who are learning to speak, can I allow them to speak? I have allowed this one too. [Points to a woman MP waiting to catch the speaker's attention]

The speaker: are you taking over my work?

Mr. Nandala-Mafabi: okay, she has sat down. Madam Speaker, we must be ready to donate blood... (Hansard, 18th August 2016)

The debate above features an interactive session in which a female minister who had been requested to give a statement spontaneously appeals for protection from the speaker of parliament a few minutes into her speech. As an observer, I noted that prior to this call, the female minister had been interrupted through loud jeers and heckling mostly from male MPs prompting her to take heed and implore the speaker for protection. The jeers and cheers which prompted the appeal for protection and the speaker's call for uninterrupted maiden speech generated even more rowdy atmosphere characterised by a mixture of prolonged laughter, heckling, stomping, jeers and applause.

One of the male legislators who stood out in this intimidating atmosphere is hon. Nandala Mafabi, a senior legislator, who at the time was the secretary general of a prominent opposition political party in parliament. Mafabi positioned himself as an authority by patronising and undermining a female minister (and other new female MPs). Male disruption and derogation of women is exemplified through hilarity as indicated in the several times the senior male MP and others in parliament laugh-off new women MPs' request for protection from interruption. While 'point of order' and 'point of information' are parliamentary procedures through which members of parliament call others to order or furnish floor holders with information regarding the debate respectively, there are no formal contexts where these carry the prefix 'maiden'. Thus, the prefix 'maiden' in both 'maiden questions' and 'maiden information' is intended to deride the new female MP and minister for exhibiting weakness by calling for the speaker's protection. Consequently, women's appeal for protection was seized upon as a marker of weakness which the male MP exploited to ridicule the female MP.

Further, hon. Mafabi thanked the minister for "coming up with a statement like that one" and ironically refers to some new female MPs as 'colleagues' who are just learning how to speak in parliament. He then follows this with a question to the speaker of parliament- "can I allow them to speak?" While he frames this as a question, it is a rhetorical one which enables him to appropriate the powers of the speaker of parliament that is, moderating parliamentary debate sessions. This sense of appropriation is reflected in the speaker's reaction about his domineering character on whether he was taking on the speaker's work. "Are you taking over my work?" At this point, the male MP covertly ignores the Speaker's concern and goes on with his submission. It is worth noting that while the speaker reprimanded the male MP for attempting to take over her powers, she ignored the way he derogates new female MPs. 
Observable in this session are subtle performances of gender (power) relations and the reactions to these, illustrating how male MPs dominate debates, intimidate and infantilise women colleagues and how women find it difficult to engage in these debates meaningfully. The complexity of these performances is exemplified through the discursive production of men and women in different subject positions and the inherent contradictions that played out in the debate session. On the one hand, the extract shows how a new female legislator invokes a legislative procedure to contest unlawful interruption of maiden speech which is granted by the speaker of parliament. On the other hand, we observe how the new female MP, far from being offered protection, is mocked and ridiculed by male colleagues for exhibiting 'weakness' by appealing for protection.

What was notable about incidents such as these, was the failure of the Hansard, the official record of parliamentary dialogue and debates, to record male intimidation and bullying of new female MPs and the expressive forms these took. Some of these included jeers, laughter, booing, stomping and other bullish behaviours which were at times recorded simply as 'laughter' or 'interruption' or not recorded at all. For example, part of the female minister's speech in which she appeals for protection is recorded as follows:

"The Uganda Transfusion Services, through its vision and mission - Madam Speaker, this is my maiden statement and for that matter (laughter) - I request that I complete the statement uninterrupted."

The above stretch of conversation hardly alerts us to the cause of the female minister's plea for protection. By omitting the rowdy moment [which I observed] that prompted the minister's appeal, the Hansard takes for granted the female legislators agential reaction to forms of bullying and intimation. Further, the Hansard's failure to record these events normalises them as acceptable ways of conduct even when they posed a challenge to women's effective engagement in debate sessions. It is through these subtle ways that the male legislator in question (and other male and female MPs) enacted gender and seniority ${ }^{3}$ to constitute gender borders and 'police' any kind of transgressive behaviour through humour, intimidation, and bullying not only of new women legislators but also those in senior leadership positions.

'Gender policing' is a term which has been coined by gender theorists and activists working in the field of education (Mayeza, 2017; Frosh et al., 2002). Accordingly, the concept refers to the process through which gender orders and gender power relations are imperfectly produced and regulated through bullying and intimidation of those who are seen as deviating from gender norms. What I found particularly surprising and significant from my ethnographic observations of gender dynamics in parliament was precisely how these operated in ways (through intimidation, bullying, regulation, and control) which constituted parliament as a difficult place for women even when there are increasing numbers of women entering parliament.

\subsection{The gendering of the maiden speech}

The actions that play out in this debate raise questions on how men and women present themselves before each other in their everyday life, the motives of investing in these subjectivities and the implications these actions have on the character of parliament. Drawing on the work of Erving Goffman on dramaturgical performances, I ask: why did particular MPs choose to present themselves before others the way they did? What functions do laughter and interjections of these kinds have? What implications do they 
have on the manner in which parliament business is conducted? [Goffman, (1959), p.2] maintains that an individual may wish others "to think highly of him or to think that he thinks highly of them, or to perceive how in fact he feels towards them...." Butler (1990, p.2) cites Foucault's notion of juridical systems of power to remind us of how subjects are 'formed, defined and reproduced' through 'limitation, prohibition, regulation, control and even 'protection'. Underlined in this structural production and representation of the subject is the discursive context in which this process takes place. The manner in which male and female MPs relate to each other is discursive and points to how they are produced by institutional structures and systems they inhabit. Goffman and Butler's theoretical resources are helpful in understanding why for instance hon. Nandala Mafabi, a senior male MP and secretary general of an opposition political party behaved in the patronising way he did before others during the maiden speech. That is, constituting himself as (an important and knowledgeable) subject by constructing women in inferior ways. Through these everyday interactions, we come to know how the context of parliament produces men as intelligible subjects and legitimate speakers in relation to women.

It is notable that while the female MPs were justified in their appeal for protection from interruption as per the parliamentary rules of procedure, there was no male MP in this particular session and other sessions that I observed who alerted the house to his making a maiden speech. In a previous study, Tamale (1999) found that women were more likely than men to be interrupted while delivering their maiden speeches despite formal rules against this kind of interruption, a finding confirmed in my own study.

\title{
4.3 Ambivalent attitude towards female MPs' oratory skills
}

In the extract, I indicated how a male MP acknowledged, with profound surprise, female colleague's ability and skill in delivering a speech on the floor of parliament. I note another similar pattern of appreciation in the extract below shortly after hon. Mafabi had thanked the female legislator for coming up with a statement like that one.

\begin{abstract}
Mr. Theodore Ssekikubo (NRM [National Resistance Movement, a ruling political party], Lwemiyaga County, Ssembabule): thank you very much, Madam Speaker. I would like to thank the minister for being prepared and indeed, she has spoken off-cuff. (Laughter) how I wish the Prime Minister could also pick a queue from the stamina and ability of the minister (interruption). (Hansard, 18th August 2016)
\end{abstract}

In this extract, (which occurs in the same sitting of parliament), hon. Ssekikubo applauds a female legislator, who also doubled as a minister for exceptional oratory skills in comparison to a senior male legislator - the Prime Minister and leader of government business. This was after the Minister had been tasked by the speaker of parliament to give a statement of the state of reported animal diseases in the country. What I highlight here is the recurrent male approval of female MPs' speech acts as exceptional and unprecedented.

The idea of acknowledging women MPs in this manner is intended to characterise the female MP's 'exceptional' debating skills as transgressive and unexpected of them and serves to silence their agency. It could also point to how men constantly monitor and evaluate women's performance in parliament on masculine standards. It is a defeminising manoeuvre - an attempt to approximate the females to the males. In Mafabi's view, such 
kind of 'excellent performance' is unexpected of a woman, especially during her first speech in an honorary space like parliament. It is a means through which men control women's conduct. Kitzinger and Wilkinson (1996, p.9) argue that dominant groups tend to control others through "control over the process of their representation." This, they add, "occurs through routine 'de-authorisation' of how others represent themselves and 'us'."

A discussion on ambivalence that comes with men's praise to women in leadership is noted by Leclerc (2006). She argues that "explicit masculine rhetoric and violent misogyny which avow women's essential emotional and intellectual incapacity is as objectifying as praising women in leadership positions since both instances have, as their motive, "approximation of women towards the masculine" [Leclerc, (2006), p.187]. In light of the above viewpoints, I view both Male MPs' apparent appreciation of women's oratory skills in parliamentary debates as a defeminising and de-authorising manoeuvre which raises questions on why men need to constantly appraise, approve and authorise women's ways of engaging in parliamentary debates. Consequently, both 'de-authorisation' as suggested by Wilkinson and Kitzinger and men's approval and appreciation of female MPs' ways of debating point to mechanisms of control.

\subsection{Women's resistance to men's bullying in parliament}

In the face of male sarcasm and bullying, both the female maiden speaker and the female speaker of parliament engaged in ways that contested and negotiated male domination. These negotiations take the form of the female MP petitioning the speaker of parliament for protection and the speaker questioning the unwarranted conduct by the male MP when she asks, "are you taking over my work?". I draw on Michel Foucault's notion of power as complex and manifested through dynamic contestations and negotiations to understand the actions of male MPs and women MPs' reactions to these instead of assuming that power is possessed by one group and denied to another. Rather than look at men in parliament as simply domineering and patronising and women, as therefore, lacking any sense of agency, dynamic power relations can be traced through reactions, responses, contestations and negotiations that female legislators engage in during the maiden speeches.

In her work on gender and parliamentary politics in Uganda, Tamale (1999) points to the pervasiveness of patriarchy as a social force that dictates much of what goes on in parliament but argues that patriarchy has been contested by women in complex ways. These, as she points out, include women forming caucuses to harness collective agency against institutionalised patriarchy as well as mobilising male support on issues perceived to be of specific interest to women. Accordingly, women's agentic interaction with men in parliamentary debates demonstrates that "gender is a basically innovative affair, although it is quite clear that there are strict punishments for contesting the script by performing out of turn or through unwarranted improvisations" [Butler, (1988), p.531]. Butler adds that gender is neither passively scripted on the body nor can it be determined by, among others, history of patriarchy but rather it is "what is put on, invariably, under constraint, daily and incessantly ...."

It is, however, important to note that certain forms of men's patronising behaviour remained unquestioned. That is, while the female speaker of parliament contested 
hon. Mafabi's attempt to take over her role of moderating parliamentary business, she nevertheless did not reprimand him for bullying women particularly the female maiden speaker or constructing women MPs as merely learning to speak in parliament. This could have implications in terms of institutionalising such kind of male patronising behaviour (and denigration of women) as normal and acceptable ways of conduct in parliament. In effect, normalising such kind of gender power relations could portray parliament a difficult space for women to express themselves and be taken seriously and possibly explains why women strategically draw on some men to speak to particular issues on behalf of women in parliamentary debates.

\section{Constructing women as other}

The idea of female MPs' secondary status to male legislators featured strongly in my observation of parliamentary debates. This was exemplified through male domination in the frequency of their submission, jeering, stomping and all manner of intimations towards women speakers in debate sessions. Below, I share one particular scenario about a male MP who helped a female colleague cross a busy road near the parliamentary building - which is linked to the first example I discussed, about the infantilisation of women in parliament by majority men. Arguably, such parliamentary debate experiences show how the institution of parliament continues to be regulated by discourses that constitute women as strangers, unexpected to perform in such political settings. Tamale $(1999$, p.118) attributes women's regulated behaviour in the legislature to "men's club character of parliament, which often treats women as intruders." I take the male MP's submission below (as recorded in the Hansard) as an illustration of normative constructions of gender in parliament which constitute men as agents in opposition to women.
Mr. John Baptist Nambeshe (NRM, Manjiya County, Bududa): thank you, Madam Speaker. I rise on a matter of urgent public importance, which was partially raised yesterday on the floor ... about the zebra crossing. However, this one is particularly on the accident-prone road called parliament avenue. Members who have offices in development house face difficulties in accessing their offices. ... This is a narrow road that has two-way traffic and our motorists and cyclists drive recklessly and have no regard for other road users. One time, a woman member of parliament took almost 10 minutes to cross until I offered to help her to cross the road. (The Hansard, 18th August 2016)

In this example, a male parliamentarian talks of how he helped a female member of parliament cross a risky road adjacent to parliament premises after she had been stuck for a significant amount of time. This submission comes shortly after the opening of the debate in a routine session called 'private members business', where any MP is free to raise any current issues they consider as of significance to the nation. Hon. Nambeshe thus characterises his submission as a follow-up on an issue of urgent public importance in which he draws parliament's attention to the dangers roads around parliament pause to MPs particularly women. He evaluates and consequently categorises the traffic situation as gruesome and a health hazard. He exemplifies this by showing us how, had it not been for his charitable gesture and protection to a female colleague, the latter would have found it even more difficult to cross the road. 


\subsection{Othering of women in parliamentary debates}

Rather than assume that the male MP is merely describing what really happened on parliamentary avenue, I draw on Butler (1988), Foucault (1978) and Speer (2005) and on particular forms of narrative analysis (Squire et al., 2008) to understand how language is used in this case to constitute subject positions for men and women in the male MP's submission in parliament. Why did the male MP narrating his experience of 'help' choose to emphasise the fact that the one he helped was a woman? If he had 'helped' a male honourable colleague, would this have been mentioned? Could a similar story have been told had the gender of the storyteller been similar to the one being helped to cross the road? Such questions provoke critical thinking about gendered identifications and the complex dynamics of power associated with them. This example of a male MP speaking about and for women in patronising ways resonates with [Kitzinger and Wilkinson's, (1996), p.8] notion of other, that is, "a psychological necessity for the development of human subjectivity." For a male MP, in a male-dominated space like parliament, highlighting his 'help' to the female colleague becomes the only possible psychological way to project ambivalent feelings of vulnerability and risk while crossing the road from himself and other men to women. In his differentiation of forms of masculinities, Connell (2005, p.78) terms this kind of othering as "the repository of whatever that is symbolically expelled from hegemonic masculinity." Thus, the male MP construction of himself as a subject necessitated the existence of an other - the female MP who would act as a depository to contain masculine ambivalent feelings of weakness and helplessness.

Women's otherness can also be read through the male MPs' infantilising behaviour towards a female MP even when both of them carry the status of 'honourable colleague'. They become like children who need help crossing a road. He seems to enhance men's honourable status by telling stories about helping women cross busy roads. Such a story presents men as chivalrous, which is usually considered a high-status male virtue. It also resonates with what it means to be an honourable man - a legislator on the one hand and a protective man on the other, both of which play out in parliament.

\subsection{Parliament's response to the zebra crossing submission}

It was noticeable that while the male MP's concern over women was presented in a way that is patronising to women, the submission generated no opposition from men and women in the session. The audiences' silence and inattention to the manner in which the male legislator expressed his submission points to possibilities of acceptable ways of the conduct of men and women in an institution like parliament. Given the notable absence of any concerns about the male MP's submission, I take this as an indication of a culture in parliament in which women are routinely constructed as in need of help from men in ways which may serve to reinforce projections of weakness onto them. Notably, the submission on the zebra crossing is not part of a motion about gender which male champions have been asked to table but a concern expressed by a male MP which was not explicitly about gender or women's rights but problems of MPs in general, in negotiating a busy road. Nevertheless, the submission provides useful insights into taken-for-granted discourses in parliament which consider men as stronger (physically and emotionally) and women as in need of help.

One point I want to make here is to show how I drew on parliament as a social context - in which I observed people interact, forge relations and position themselves in 
particular ways, or in Goffman's terms, a 'setting' [Burns, (1992), p.116]. I note that parliamentary debate sessions are a setting upon which female and male MPs act before each other in, appropriately acceptable ways, to enhance their perceived sense of self. The context of parliament consequently creates and reproduces men as adept while negating women in parliamentary debates.

\subsection{How gendering of parliament compares with sociological ways of doing gender in other institutional settings}

The manner in which gender power relations are learned and conveyed in parliament resonates with issues about the regulation and policing gender which have been raised in ethnographic studies in primary schools such as Mayeza (2017) and Thorne (1993). While parliament might be seen as far removed from the school playground (in as far as it is constituted as an honorary space where important legislative work is done by elite politicians), Mayeza's ethnography of primary school play, just like my study of parliamentary interactions provides similar insights concerning the dynamics and performances of gender in these two different contexts. Just as male MPs dominate proceedings in parliamentary debates, so the playground in Mayeza's study is constructed as a male space (in which football is played) and where girls are confined to the margins, on the periphery. In Mayeza's study, those girls who exhibit skills in what is perceived as masculine, are ridiculed, mocked and laughed at. Similar patronising behaviour is seen in my study through male MPs mocking female maiden speakers and not taking seriously female MPs' debating skills.

This comparison provides insights into how gender identities are produced, reproduced and enacted through everyday practices such as play in schools and legislative procedures in parliament. The examples I draw on underscore the role of institutions (in this case, parliament and school) in producing gendered subjects. That is to say that institutions are not merely spaces where official business goes on as per the formal rules and regulations. Rather, they are contexts where males and females engage in complex relations characterised by different forms of domination as well as contesting and negotiating these.

On the whole, the examples on which I draw in this paper, namely the reactions to the maiden speeches and the gendered concerns raised about crossing the busy road alert us to the explicit and implicit ways gendered messages are conveyed through what legislators say and do in parliament. Importantly, these examples reveal ways in which parliament is constituted in problematic ways, as a space in which men more audible, visible and 'legitimate' actors in legislative debates in relation to women.

\section{Conclusions}

I have shown how working with the Hansard alone is limiting as a way of recording what happens in parliament and in particular the kind of implicit messages communicated about gender through everyday interactions between parliamentarians. I have also pointed out how these omissions provide us with glimpses on the normativity of gender inequalities in parliament. For example, I pay close attention to the rowdy interactions amongst MPs which are recorded simply as 'interruptions'. Yet, these omissions - 
boorish and all manner of unwelcome behaviours - which I was able to pick up through ethnographic observation constituted insightful data to my research on everyday performances of gender and power and how these constrained women's participation in parliamentary debates.

Additionally, I have indicated how an ethnographic approach to studying parliament unearths and pays attention to taken for granted micro-sociological aspects of individual human interaction, which, when repeatedly enacted, and re-enacted, become 'stylised into gendered modes' [Butler, (1988), p.526] and consequently acceptable ways of public conduct. Some of the taken-for-granted aspects could be the subtlety, hilarity, and silence that parliamentary context accords to such performances of gender and power even when they constrain women MPs' participation. Further, ethnographic observation of parliament as a social context has elaborated new ways of studying the micro and the macro, gendered and the gender neutral and gender-blind practices, and the overt and covert experiences of female and male legislators. I argue that it is the subtle and seemingly unrecognisable everyday practices of female and male legislators in parliament that come to constitute parliament as a gendered institution.

The day to day MPs' interactions resonate with what Butler identifies as the 'stylised repeated acts' that institutionalise gender performances as natural and acceptable ways of conduct. Repeated interactions between female and male MPs that are characterised by bullying, heckling, jeering, sarcasm, male patronage can be seen as gender policing practices which make it difficult for women - who are constituted in mundane ways, as weak, inaudible and in need of men's protection - to present and debate ideas particularly on women's rights. In effect, these practices reproduce gender binaries, constituting women as intruders and men as 'natural' actors in parliament. It is through such gendered relational dynamics which regulate how women ought to speak, when, where and on what issues that the idea of men as spokespersons of women becomes conceivable.

The study also demonstrates how male MPs draw on patriarchal discourses that promote public politics as a masculine preserve, to enhance their status as legislators while at the same time excluding women whom they constitute in patronising ways. Observations showed how female legislators are repeatedly ridiculed, bullied, infantilised, laughed at. In other cases, they are subjected to intense scrutiny characterised by both approvals and dismissal of their debating capacities in ways that male legislators are hardly evaluated. Even when there are observably higher numbers of women in parliament, and cases of pro-women legislation being debated and passed into law, nevertheless, these subtle and everyday practices indicate just how problematic parliament is for women. Perhaps, it is hardly surprising that women opt to identify some men to speak to pro-women legislation as a strategic move to negotiate patriarchal resistance in parliamentary debates.

Analysis of parliament as an institution has shed light on the process through which categories of 'women' and 'men' in parliament are formed, defined and reproduced in everyday parliamentary debate sessions. This is realised through formal and informal rules and regulations and MPs' actions and reactions to these. The manner in which these took a gendered character with women more often than men being patronised and infantilised and finding parliament a problematic space for them carries implications for my research that aims to explore how and why women recruit men as allies to speak on their behalf in such a context. On the one hand, the research demonstrates why, in order to be taken seriously, female MPs may opt for men to introduce and speak to motions concerned with promoting women's rights. On the other hand, it raises questions about 
the institutionalisation of gender power relations in parliament and whether the very construction of 'male champions' as such men have come to be categorised, contributes to the institutionalisation of unequal gender power dynamics.

\section{References}

Ahikire, J. and Mwiine, A.A. (2015) The Politics of Promoting Gender Equity in Contemporary Uganda: Cases of the Domestic Violence Law and the Policy on Universal Primary Education, Manchester, UK.

Ahikire, J., Musiimenta, P. and Mwiine, A.A. (2015) 'Making a difference: embracing the challenge of women's substantive engagement in political leadership in Uganda', Feminist Africa, No. 20, pp.23-42 [online] http://www.agi.ac.za/agi/feminist-africa/20/.

Andrews, M., Squire, C. and Tamboukou, M. (2008) 'Narratives of events: Labovian narrative analysis and its limitations', in Andrews, M., Squire, C. and Tamboukou, M. (Eds.): Doing Narrative Research, pp.23-41, Sage Publications Ltd., London.

Bryman, A. (2012) Social Research Methods, 4th ed., Oxford University Press, Oxford.

Burns, T. (1992) Erving Goffman, Routledge, London and New York.

Butler, J. (1988) 'Performative acts and gender constitution: an essay in phenomenology and feminist theory', Theatre Journal, Vol. 40, No. 4, pp.519-531.

Butler, J. (1990) Gender Trouble: Feminism and the Subversion of Identity, Routledge, New York.

Carlson, K. and Randell, S. (2013) 'Gender and development: working with men for gender equality in Rwanda', Agenda, Vol. 27, No. 1, pp.114-125.

Connell, R. (2005) Masculinities, 2nd ed., Polity Press, Cambridge.

Cortazzi, M. (2001) 'Narrative analysis in ethnography', in Atkinson, P. et al. (Eds.): Handbook of Ethnography, pp.384-394, Sage Publications, London.

Foucault, M. (1978) The History of Sexuality Volume 1: an Introduction, Pantheon Books, New York.

Frosh, S., Phoenix, A. and Pattman, R. (2002) Young Masculinities: Understanding Boys in Contemporary Society, Palgrave Macmillan, New York.

Goffman, E. (1959) The Presentation of Self in Everyday Life, Doubleday, New York.

Kitzinger, C. and Wilkinson, S. (1996) 'Theorising representing the other', in Wilkinson, S. and Kitzinger, C. (Eds.): Representing the Other: Feminism and Psychology Reader, pp.1-32, Sage Publications, London, Thousand Oaks, New Delhi.

Leclerc, D. (2006) 'Two women speaking 'woman': the strategic essentialism of Luce Irigaray and Phoebe Palmer', in Jule, A. and Pedersen, B.T. (Eds.): Being Feminist, Being Christian, pp.182-199, Palgrave Macmillan, New York.

Madanda, A. (2017) 'Inclusion and exclusion: the case of gender equallity in the 2016 elections', in Oloka-Onyango, J. and Ahikire, J. (Eds.): Controlling Consent: Uganda's 2016 Elections, pp.173-192, Africa World Press, New Jersey.

Mayeza, E. (2017) 'Girls don't play soccer': children policing gender on the playground in a township primary school in South Africa', Gender and Education, Vol. 29, No. 4, pp.476-494.

Palmieri, S. (2013) 'Sympathetic advocates: male parliamentarians sharing responsibility for gender equality', Gender \& Development, Vol. 21, No. 1, pp.67-80.

Pillow, W.S. and Mayo, C. (2012) 'Feminist ethnography: histories, challenges, and possibilities', in Hesse-Biber, S.N. (Ed.): Handbook of Feminist Research: Theory and Praxis, pp.187-205, Sage Publications, Inc., Thousand Oaks. 
Powley, E. and Pearson, E. (2007) “Gender is society': inclusive lawmaking in Rwanda's Parliament', Critical Half: Bi-Annual Journal of Women for Women International, Winter, Vol. 5, No. 1, pp.15-19.

Riessman, C. (2001) 'Analysis of personal narratives', in Holstein, J.A. and Gubrium, J.F. (Eds.): Handbook of Interviewing, pp.695-710, Sage Publications, Inc., London.

Riessman, C.K. (1993) Narrative Analysis, Sage Publications, Inc., Newbury, London and New Delhi.

Skeggs, B. (2001) 'Feminist ethnography', in Atkinson, P. et al. (Eds.): Handbook of Ethnography, pp.426-442, Sage, London.

Speer, S.A. (2005) Gender Talk: Feminism, Discourse and Conversation Analysis, Routledge, New York.

Squire, C., Andrews, M. and Tamboukou, M. (2008) 'Introduction: what is narrative research?', in Andrews, M., Squire, C. and Tamboukou, M. (Eds.): Doing Narrative Research, pp.1-22, Sage Publications, Ltd., London.

Tamale, S. (1999) When Hens Begin to Crow: Gender and Parliamentary Politics in Uganda, Fountain Publishers, Kampala.

Thorne, B. (1993) Gender Play, Girls and Boys in School, Open University Press, Buckingham.

UWOPA (2016) Strategic Plan 2016-2021: Promoting Gender Parity in Policies and Development, Kampala.

Wang, V. (2013) 'Women changing policy outcomes: learning from pro-women legislation in the Ugandan parliament', Women's Studies International Forum, Vol. 41, No. 2, pp.113-121.

West, C. and Zimmerman, D.H. (1987) 'Doing gender', Gender \& Society, Vol. 1, No. 2, pp.125-151.

\section{Notes}

1 Women registered public presence though as a separate category in opposition to men.

2 Also see Wang (2013).

3 Senior in the sense that he has spent more than one term of office in parliament. 